\title{
Kontruksi Sistem Jaminan Sosial dalam Perspektif Ekonomi Islam
}

\author{
Naerul Edwin Kiky Aprianto \\ Institut Agama Islam Negeri Purwokerto \\ email: naerul_edwin@yahoo.com
}

\begin{abstract}
This article intends to examine the social security system in the perspective of Islamic economy. Using literature review, this article cut social security. For that, it can be concluded that the social security construction in the Islamic economic system has four stages, namely: (1) guarantees the individual against himself (individual guarantees); (2) among individuals with his family (family guarantees); (3) individuals with society (assurance society); and (4) between people within a country (a guarantee). Therefore, the construction of social security system in Islamic economics illustrates that guarantee it in layers. When social security was able to be resolved by the individual, then simply at the level of the individual. But when could not be resolved at the level of the individual, it will be resolved at the level of the family. If not completed in level of the family, it will be resolved at the community level. If social security did not complete in the community, then the obligation of the State to finish it
\end{abstract}

Keywords: Construction; System, Social Security; Islamic Economics.

\begin{abstract}
Abstrak: Artikel ini bermaksud untuk mengkaji sistem jaminan sosial dalam perspektif ekonomi Islam. Dengan menggunakan literature review, artikel ini membedah jaminan sosial Islam. Artikel ini menyimpulkan bahwa konstruksi jaminan sosial dalam ekonomi Islam memiliki empat sistem tahapan, yaitu: (1) jaminan individu terhadap dirinya (jaminan individu); (2) antara individu dengan keluarganya (jaminan keluarga); (3) individu dengan masyarakatnya (jaminan masyarakat); dan (4) antara masyarakat dalam suatu negara (jaminan negara). Oleh karena itu, konstruksi sistem jaminan sosial dalam ekonomi Islam menggambarkan bahwa jaminan itu berlapis-lapis. Apabila jaminan sosial mampu diselesaikan oleh individu, maka cukup di level individu. Apabila tidak bisa diselesaikan di level individu, maka akan diselesaikan di level keluarga. Apabila tidak selesai di level keluarga, maka akan diselesaikan di level masyarakat. Apabila jaminan sosial tidak selesai di masyarakat, maka kewajiban negara menyelesaikannya
\end{abstract}

Kata Kunci: Konstruksi; Sistem; Jaminan Sosial; Ekonomi Islam. 


\section{Pendahuluan}

Kemiskinan merupakan permasalahan yang selalu ada di setiap negara, baik dalam bentuk kemiskinan yang sifatnya absolut maupun kemiskinan relatif. Masalah kemiskinan ini harus diupayakan penyelesaiannya, sebab jika tidak mampu diselesaikan, maka akan menjadi permasalahan yang dapat mengganggu aktivitas perekonomian. Al-Qardhawi menjelaskan bahwa pandangan Islam tidak membenarkan seseorang yang hidup di tengah masyarakat Islam sekalipun ahl aldhimmah (warga negara non-muslim) menderita lapar, tidak berpakaian, menggelandang (tidak bertempat tinggal), dan ajaran Islam menyatakan perang terhadap kemiskinan dan berusaha keras untuk membendungnya serta mengawasi kemungkinan yang dapat menimbulkannya (al-Qardhawi 2002). Hal itu dilakukan dalam rangka menyelamatkan akidah, akhlak dan perbuatan, memelihara kehidupan rumah tangga, melindungi kestabilan serta ketenteraman masyarakat, di samping mewujudkan jiwa persaudaraan antara sesama anggota masyarakat. Oleh karena itu, permasalahan kemiskinan sebagai ancaman bagi masa depan negara jika tidak ditangani serius oleh pemerintah dan semua elemen masyarakat (Qadir 2001).

Islam sebagai sebuah ajaran telah menawarkan beberapa doktrin bagi manusia yang berlaku secara universal dengan dua ciri dimensi, yaitu kebahagiaan di dunia dan kebahagiaan hidup di akhirat (Aedy 2011). Namun dalam kenyataannya, tidak semua warga negara dapat dengan mudah mendapatkan kesejahteraan. Berbicara tentang masalah kesejahteraan dalam Islam, tentunya hal tersebut tidak dapat dilepaskan dengan pembahasan mengenai jaminan sosial.

Dalam ekonomi kapitalisme, jaminan sosial tidak dibahas secara rinci. Akan tetapi, sistem ini hanya menekankan kepada kebebasan penuh yang dimiliki oleh setiap individu, baik dalam kepemilikan harta yang mutlak, cara memilikinya sampai dengan penggunaannya merupakan 
hak mutlak setiap individu yang tidak dapat diintervensi oleh siapa pun, termasuk pemerintah. Sementara itu, ekonomi sosialisme berusaha mewujudkan jaminan sosial melalui persamaan dalam kepemilikan, di mana kepemilikan harta dikuasai sepenuhnya oleh negara. Sedangkan ekonomi Islam benar-benar menjamin kebutuhan-kebutuhan individu tanpa melarang kepemilikan individu (al-Arif 2015).

Menurut M. Umer Chapra, Islam menganjurkan kesejahteraan ekonomi melalui pemenuhan semua kebutuhan pokok manusia, menghapuskan semua sumber utama kesulitan dan ketidaknyamanan (kemiskinan, pengangguran, kesempatan kerja yang rendah, dan lainlain), serta meningkatkan kualitas kehidupan secara moral dan material (M. U. Chapra 1992). Sementara itu, menurut Jaih Mubarok bahwa kesejahteraan adalah perasaan-perasaan hidup senang dan tenteram tidak kurang apa-apa dalam batas yang mungkin dicapai oleh orangperorang (Mubarok 2008).

Tahapan-tahapan kesejahteraan sebagaimana teori need milik Abraham Maslow seperti dikutip oleh Mukhlisin Muzarie bahwa kesejahteraan sosial meliputi beberapa aspek yang diperoleh secara bertahap dan berurutan. Tahap pertama adalah terpenuhinya kebutuhan fisik (physioligical needs) atau kebutuhan pokok (basic needs) seperti pangan, sandang, papan, pendidikan dan kesehatan. Tahap kedua adalah kebutuhan akan rasa aman (safety needs), kemudian diikuti tahap ketiga yaitu kebutuhan sosial (social needs). Tahap keempat adalah kebutuhan akan pengakuan (esteem needs), dan tahap kelima (terakhir) adalah terpenuhinya kebutuhan aktualisasi diri (self actualization needs) (Muzarie 2010). Oleh karena itu, tulisan ini bermaksud untuk mengkaji konstruksi sistem jaminan sosial dalam perspektif ekonomi Islam. 


\section{Definisi Jaminan Sosial}

Jaminan sosial secara etimologi terdiri atas dua kata, yaitu jaminan dan sosial. Dalam hal ini, jaminan merupakan tanggungan atas pinjaman yang diterima atau janji satu pihak untuk menanggung kewajiban pihak lain. Sedangkan sosial adalah sesuatu yang berkenaan dengan masyarakat atau rakyat. Kedua arti tersebut, jika dianalogikan pihak yang satu adalah negara serta pihak yang lain adalah masyarakat (warga negara), sehingga dapat diambil sebuah pengertian bahwa seseorang dalam suatu negara wajib untuk menyetorkan iuran kepada negara secara kolektif dan universal guna menanggung dan menjamin kehidupan setiap warga negaranya yang membutuhkan (Syufa'at 2015).

Menurut Monika Queisser, tidak ada definisi baku yang menyumbangkan pemaknaan jaminan sosial secara global. Menurutnya, jaminan sosial sebenarnya dipahami sebagai jumlah total semua nilai atau aturan sosial yang dirancang tidak hanya untuk menjamin kelangsungan hidup fisik suatu kelompok individu atau masyarakat, tetapi juga untuk memberikan perlindungan yang komprehensif dari risiko yang mungkin mengacu pada penurunan daya hidup yang tidak dapat diramalkan dan konsekuensi yang dapat ditanggung sendiri oleh mereka yang terkena dampak (Queisser 1995). Sementara itu, Purwoko mengemukakan bahwa konsep jaminan sosial sebagai suatu skema proteksi yang ditujukan untuk tindakan pencegahan, khususnya bagi masyarakat yang memiliki penghasilan terhadap berbagai risiko atau peristiwa yang terjadi secara alami sperti sakit, kecelakaan, kematian, PHK sebelum usia pensiun, dan hari tua (Purwoko 2010). Oleh karena itu, kehadiran jaminan sosial adalah selain untuk menjamin atau melindungi individu secara fisik, juga untuk meminimalisir adanya risiko yang mungkin terjadi.

Di dalam Undang-Undang Nomor 40 Tahun 2004 tentang Sistem Jaminan Sosial Nasional disebutkan bahwa jaminan sosial adalah salah 
satu bentuk perlindungan sosial untuk menjamin seluruh rakyat agar dapat memenuhi kebutuhan dasar hidupnya yang layak (2004 n.d.). Menurut Afzalur Rahman, jaminan sosial dalam Islam mencakup pemberian standar hidup yang layak, termasuk penyediaan pangan, pakaian, perumahan, kesehatan, pendidikan, dan lain sebagainya (Rahman, Doktrin Ekonomi Islam 1995).

Islam meninggalkan pesan-pesan melalui sejarah kebudayaan yang erat dengan keadilan dan kesejahteraan. Keadilan sosial ini tentu saja bukan hanya untuk negara Islam, namun konsep ini harus dimiliki oleh semua negara di dunia. Jika meninjau kembali skema jaminan sosial yang berujung pada kesejahteraan, maka dalam prosesnya terdapat distribusi kekayaan dalam bentuk penjaminan. Sedangkan dana jaminan dalam hal ini salah satunya adalah diambil dari dana warga negaranya, yaitu berupa zakat, infak, dan sedekah (al-Qashim 2006). Selain itu, Umar Chapra menegaskan bahwa kewajiban untuk menciptakan suatu kesejahteraan yang dicerminkan dengan adanya penjaminan pun diwajibkan bagi manusia baik individu maupun kolektif, terlebih negara yang bertugas menaungi seluruh warganya (M. U. Chapra, The Islamic Welfare State and its Role in The Economy 1995).

Dengan demikian, dapat dipahami bahwa jaminan sosial merupakan salah satu bentuk perlindungan sosial yang diberikan kepada masyarakat, baik dalam bentuk sandang, pangan, papan, kesehatan, pendidikan, keamanan, dan keadilan bagi usia produktif maupun usia lanjut. Dengan tambahan penjelasan bahwa tunjangan hari tua hanya akan diberikan setelah seseorang melewati batas usia produktif. Sedangkan untuk jaminan keamanan, keadilan, pemerataan ekonomi yang terangkum dalam sandang, pangan, dan papan adalah hak masyarakat baik dalam usia produktif maupun non-produktif. 


\section{Asas-asas Jaminan Sosial dalam Islam}

Asas jaminan sosial dirumuskan dalam tiga hal, yaitu asas kemanusiaan, asas manfaat, dan asas keadilan (Syufa'at 2015). Dalam hal ini, asas kemanusiaan merupakan asas yang bersinggungan dengan martabat manusia. Asas tersebut untuk mengangkat dan melindungi harga diri manusia sebagai hak dasar bagi seluruh warga negara. Sebagaimana yang terdapat dalam al-Qur'an bahwa adanya persamaan antar manusia di hadapan Allah swt, hanya saja yang membedakan adalah ketakwaannya sebagaimana firman Allah swt. dalam QS. alHujurat [49]: 13:

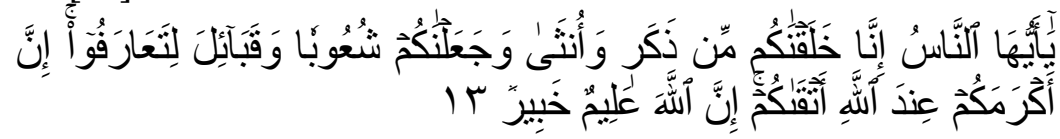

"Hai manusia, sesungguhnya Kami menciptakanmu dari seorang laki-laki dan seorang perempuan dan menjadikanmu berbangsabangsa dan bersuku-suku supaya kalian saling kenal-mengenal. Sesungguhnya orang yang paling mulia di antaramu di sisi Allah ialah orang yang paling takwa di antaramu. Sesungguhnya Allah Maha Mengetahui lagi Maha Mengenal." (QS. al-Hujurat [49]: 13)

Asas manfaat tercermin dengan pemberian nilai tunai dan pelayanan kesehatan sesuai dengan kebutuhan pokok bagi kehidupan seseorang yang layak, seperti sandang, pangan, papan, penjaminan pensiun, tabungan hari tua, kesehatan, kecelakaan kerja, kematian, pendidikan, serta perumahan, sebagaimana firman Allah swt. dalam QS. al-Nisa [4]: 36:

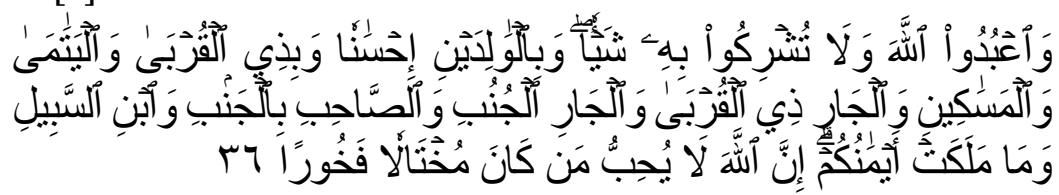

"Sembahlah Allah dan janganlah kalian mempersekutukan-Nya dengan sesuatu pun. Dan berbuat baiklah kepada kedua orang tua, karib-kerabat, anak-anak yatim, orang-orang miskin, tetangga yang dekat dan tetangga yang jauh, dan teman sejawat, ibnu sabil dan 
hamba sahayamu. Sesungguhnya Allah tidak menyukai orang-orang yang sombong dan membangga-banggakan diri." (QS. al-Nisa [4]: 36)

Asas keadilan berarti jaminan yang didistribusikan adalah merata kepada seluruh warga negara dengan tidak memandang status, pangkat, jabatan, kaya, hampir miskin, dan bahkan miskin sekalipun akan mendapatkan perlakuan dan hak yang sama, sebagaimana firman Allah swt. dalam QS. al-Ma'idah [15]: 8:

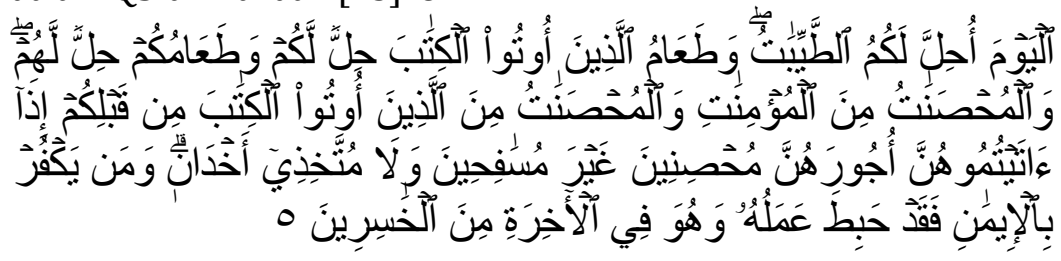

"Wahai orang-orang yang beriman, jadilah kalian sebagai penegak keadilan karena Allah (ketika) menjadi saksi dengan adil. Dan janganlah kebencianmu terhadap suatu kaum mendorongmu untuk berlaku tidak adil. Berlaku adillah, karena (adil) itu lebih dekat kepada takwa. Dan bertakwalah kepada Allah, sesungguhnya Allah Maha mengetahui apa yang kalian kerjakan." (QS. al-Ma'idah [5]: 8)

Ketiga asas ini merupakan landasan asas yang sustainable dan relatable, di mana antara asas yang satu dengan yang lain akan saling berdampingan dan tidak dapat berdiri sendiri untuk menopang dari sifat jaminan sosial. Artinya, menghilangkan satu asas dari ketiga asas tersebut dalam sistem jaminan sosial, maka akan mengurangi makna dari jaminan sosial itu sendiri.

\section{Sistem Jaminan Sosial dalam Ekonomi Islam}

Jaminan sosial sering diartikan sebagai kesejahteraan sosial (social welfare). Istilah kesejahteraan sosial merupakan kondisi terpenuhinya kebutuhan material dan non-material. Dalam hal ini, kondisi sejahtera terjadi manakala kehidupan manusia aman dan bahagia karena 
kebutuhan dasar akan gizi, kesehatan, pendidikan, tempat tinggal, pendapatan dapat dipenuhi, serta manakala manusia memperoleh perlindungan dari risiko-risiko utama yang mengancam kehidupannya (Dahlan 2007).

Pada tinjauan yang lebih luas seperti yang telah diterapkan dan dilaksanakan oleh berbagai negara di dunia, jaminan sosial tidak hanya berporos pada terwujudnya kesejahteraan masyarakat saja. Namun demikian, jaminan sosial telah bermetamorfosa menjadi sebuah sistem, di mana sistem tersebut dibangun sesuai dengan identitas dan kondisi masing-masing negara. Menurut Subianto, jaminan sosial sebagai suatu sistem akan dapat memberikan energi bagi setiap warga negara untuk membangun cita-cita negaranya menuju masyarakat yang adil, makmur, dan sejahtera (Subianto 2011).

Aplikasi dan pemahaman jaminan sosial sebagai suatu sistem yang baik sesuai dengan filosofinya akan mengantarkan pada kondisi negara yang sejahtera, aman, stabil dalam berbagai bidang, mengembangkan ekonomi negara baik mikro maupun makro. Hal ini senada dengan pandangan Muhammad Akram Khan yang menjelaskan bahwa kesejahteraan (falāh) meliputi kelangsungan hidup, kebebasan berkeinginan, serta kekuatan dan harga diri dengan beberapa aspek yang dipenuhi baik secara mikro maupun makro. ${ }^{1}$

\footnotetext{
1 Untuk dapat melangsungkan kehidupan, maka secara mikro manusia membutuhkan pemenuhan kebutuhan biologis seperti kesehatan fisik atau bebas dari penyakit, dalam tataran ekonomi memerlukan kepemilikan faktor produksi, secara sosial memerlukan persaudaraan dan hubungan antarpersonal yang harmonis, dan dalam tataran politik memiliki kebebasan untuk berpartisipasi. Secara makro kelangsungan hidup menuntut adanya keseimbangan ekologi, pengelolaan SDA, dan kebersamaan sosial. Untuk dapat bebas berkeinginan, manusia harus bebas dari kemiskinan dan memiliki kemandirian hidup, sementara pada lingkup makro harus tersedia sumber daya bagi penduduk masa sekarang dan generasi yang akan datang. Adapun untuk bisa memiliki kekuatan dan harga diri, secara mikro setiap orang harus memiliki kemerdekaan, perlindungan terhadap hidup, dan secara makro harus memiliki kekuatan
} 
Islam telah menugaskan negara untuk menyediakan jaminan sosial guna memelihara standar hidup seluruh individu dalam masyarakat Islam. Lazimnya, negara menunaikan kewajibannya ini dalam dua bentuk. Pertama, negara memberi individu kesempatan yang luas untuk melakukan kerja produktif, sehingga ia bisa memenuhi kebutuhan hidupnya dari kerja dan usahanya sendiri. Namun, ketika seorang individu tidak mampu melakukan kerja produktif dan memenuhi kebutuhan hidupnya dari usahanya sendiri atau ketika ada keadaan khusus di mana negara tidak bisa menyediakan kesempatan kerja baginya, maka berlakulah bentuk kedua. Dalam hal ini, bentuk kedua adalah negara mengaplikasikan prinsip jaminan sosial dengan cara menyediakan uang dalam jumlah yang cukup untuk membiayai kebutuhan individu tersebut dan untuk memperbaiki standar hidupnya.

Islam telah memberikan konsep yang lengkap tentang jaminan sosial, di mana konstruksi sistem jaminan sosial dalam Islam memiliki empat tahapan, sebagaimana dapat dilihat pada gambar berikut ini:

Gambar 1. Konstruksi Sistem Jaminan Sosial dalam Islam

ekonomi, terbebas dari hutang, dan bahkan memiliki kekuatan militer yang tangguh (Khan, An Introduction to Islamic Economics 1994).

Economica: Jurnal Ekonomi Islam - Volume 8, Nomor 2 (2017) http://journal.walisongo.ac.id/index.php/economica 


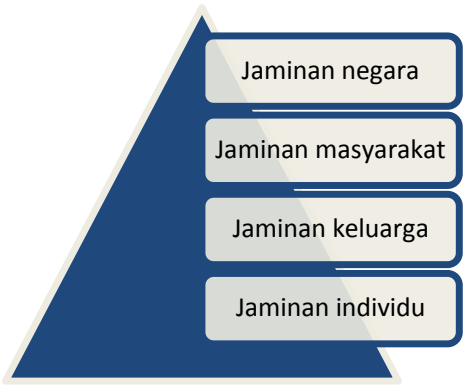

Berdasarkan konstruksi tersebut, sistem jaminan sosial dalam ekonomi Islam meliputi jaminan individu terhadap dirinya (jaminan individu), antara individu dengan keluarganya (jaminan keluarga), individu dengan masyarakatnya (jaminan masyarakat), dan antara masyarakat dalam suatu negara (jaminan negara). Keempat jaminan tersebut dapat dijabarkan sebagai berikut:

\section{Jaminan Individu}

Jaminan ini menekankan bahwa setiap individu bertanggung jawab agar dirinya terlindung dari hawa nafsu, selalu melakukan pembersihan jiwa, menempuh jalan yang baik dan selamat, tidak menjerumuskan diri dalam kehancuran, dan bekerja keras agar mampu memenuhi kebutuhannya. Oleh karena itu, jaminan individu ini menuntut supaya seseorang termotivasi untuk bekerja keras dalam rangka untuk memenuhi kebutuhan hidupnya. Hal ini didasarkan atas firman Allah swt. dalam QS. al-Taubah [9]: 105:

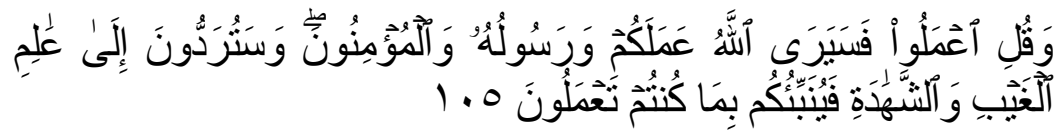

"Dan katakanlah: Bekerjalah kalian, maka Allah dan Rasul-Nya serta orang-orang mukmin akan melihat pekerjaanmu itu, dan kalian akan dikembalikan kepada (Allah) yang mengetahui akan yang gaib dan yang nyata, lalu diberitakan-Nya kepadamu apa yang telah kalian kerjakan." (QS. al-Taubah [9]: 105) 
Berdasarkan ayat di atas, Quraish Shihab memandang bahwa ayat tersebut sangat berkaitan dengan masalah kemiskinan. Islam memandang bahwa masalah kemiskinan adalah masalah tidak terpenuhinya kebutuhan-kebutuhan primer secara menyeluruh. Sejak dahulu hingga sekarang, syariat Islam telah menentukan kebutuhan primer itu (yang menyangkut eksistensi manusia) berupa tiga hal, yaitu sandang, pangan, dan papan (Shihab 1996). Oleh karena itu, dengan bekerja keras, maka seseorang akan terhindar dari kemiskinan dan kesulitan dalam memenuhi kebutuhan hidupnya.

Dengan bekerja, seseorang juga akan memperoleh kehidupan yang lebih baik, sehingga kesejahteraan dan kemakmuran akan semakin tinggi, sebagaimana sabda Rasulullah Saw.:

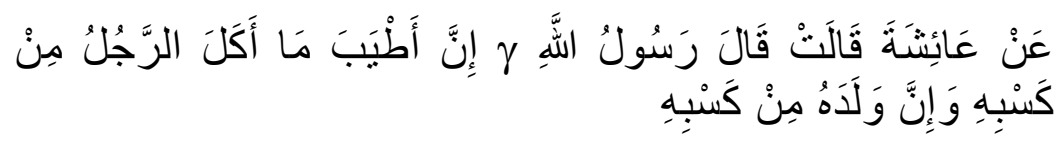

"Dari Aisyah, ia berkata, bahwa Rasulullah saw. bersabda: Sesuatu yang paling baik untuk dimakan oleh seseorang adalah dari jerih payahnya, dan anak adalah termasuk dari jerih payahnya." (HR. Ibnu Majah)

Menurut Isnaini Harahap, hadis di atas memberikan maksud bahwa Rasulullah saw. menekankan pada pembangunan sumber daya manusia. Beliau sangat mengapresiasi dan memberikan nilai yang tinggi pada seseorang yang bekerja. Ketergantungan kepada orang lain, sikap berpangku tangan atau mengemis/meminta-minta sebagai sarana untuk memenuhi kebutuhan hidup sangat dicela. Manusia didorong untuk bekerja keras, membangun segala sarana ekonomi, memproduksi barang dan jasa, dan dilarang membuang waktu percuma dengan berpangku tangan melakukan aktivitas yang produktif (Isnaini Harahap 2015).

Dengan demikian, jaminan individu ini diarahkan untuk mencapai maqāṣid syarīah (tujuan-tujuan syariah) yang meliputi pemeliharaan terhadap agama (hifz al-dīn); pemeliharaan terhadap jiwa (hifẓ al-nafs); 
pemeliharaan terhadap akal (hifz al-'aql); pemeliharaan terhadap keturunan (hifz al-nasl); dan pemeliharaan terhadap harta (hifz al-māl), sehingga akan tercapainya falāh atau kesejahteraan dunia dan akhirat (A. A. Karim 2014).

Konsep ini dapat diimplementasikan bahwa jaminan sosial semestinya mengarahkan pada kehidupan agama yang harmonis sebagai refleksi dari hifž al-dīn, memberdayakan manusia yang mampu memenuhi kebutuhan hidup sebagai implementasi dari hifz al-nafs, meningkatnya sumber daya manusia yang beriman, cerdas, dan terampil sebagai refleksi dari hifz al-'aql, meningkatnya kesejahteraan keluarga dengan adanya peluang kerja yang baik dan distribusi pendapatan yang merata sebagai refleksi dari hifz al-nasl, dan meningkatnya pendapatan individu secara finansial dan kemauan untuk mendistribusikannya dengan membagi kepada orang yang membutuhkan sebagai refleksi dari hifẓ al-māl.

\section{Jaminan Keluarga}

Setiap individu pada akhirnya membangun sebuah keluarga. Islam mengajarkan bahwa terdapat hak dan kewajiban baik material dan nonmaterial yang harus ditunaikan antara satu dengan yang lainnya. Untuk itu, seorang kepala keluarga berkewajiban memberikan nafkah lahir dan batin terhadap keluarganya.

Jaminan sosial antara individu dengan keluarganya adalah disyariatkannya hukum waris. Dalam hal ini, waris diartikan sebagai perpindahan hak kepemilikan dari orang yang telah meninggal dunia kepada ahli waris (Isnaini Harahap 2015). Oleh sebab itu, waris merupakan salah satu sarana memperoleh jaminan sosial. Lahirnya konsep waris sebagaimana yang telah diterangkan dalam al-Qur'an menempati posisi fundamental dalam ajaran Islam. Hal ini dapat 
dibuktikan dengan penjelasan dasar-dasar sistem kewarisan Islam pada ayat-ayat al-Qur'an sebagaimana dalam QS. al-Nisa [4]: 176:

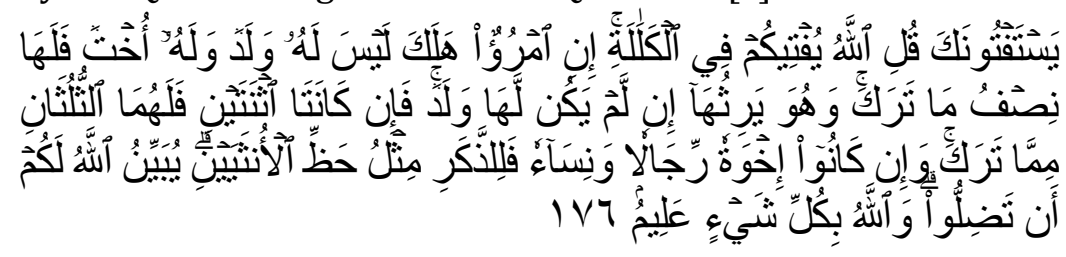

"Mereka meminta fatwa kepadamu (tentang kalälah). Katakanlah: "Allah memberi fatwa kepadamu tentang kalālah (yaitu): jika seorang meninggal dunia dan ia tidak mempunyai anak dan mempunyai saudara perempuan, maka bagi saudaranya yang perempuan itu seperdua dari harta yang ditinggalkannya, dan saudaranya yang laki-laki mempusakai (seluruh harta saudara perempuan), jika ia tidak mempunyai anak; tetapi jika saudara perempuan itu dua orang, maka bagi keduanya dua pertiga dari harta yang ditinggalkan oleh yang meninggal. Dan jika mereka (ahli waris itu terdiri dari) saudara-saudara laki dan perempuan, maka bagian seorang saudara laki-laki sebanyak bahagian dua orang saudara perempuan. Allah menerangkan (hukum ini) kepadamu, supaya kalian tidak sesat dan Allah Maha Mengetahui segala sesuatu." (QS. al-Nisa [4]: 176)

Berdasarkan ayat di atas, kalimat al-kalālah di ambil dari kata al-iklīl, yakni sesuatu yang melingkup seluruh kepala. Ada juga yang berpendapat dari kata al-kalla yang bermakna lemah. Misalnya, kata ini digunakan dalam kalla al-rajulu yang artinya "apabila orang itu lemah dan hilang." Sedangkan yang dimaksud di sini ialah orang yang hanya memiliki ahli waris dari kaum kerabatnya saja (Kathīr 2000).

Islam telah mengajarkan adanya warisan tanpa diskriminasi antara laki-laki dan perempuan sehingga penyebaran harta menjadi sangat luas (Chaudhry 2012). Jika dicermati lebih jauh, mekanisme waris sangat erat dengan jaminan sosial dalam mewujudkan keluarga yang sejahtera jauh dari kemiskinan. Dengan warisan, Islam ingin memastikan bahwa aset dan kekuatan ekonomi tidak terpusat pada seseorang saja. Betapa pun 
kayanya seseorang, jika seorang bapak meninggal dunia, maka anak, istri, ibu, dan kerabat lainnya akan memperoleh harta peninggalannya, sebagaimana sabda Rasulullah saw.:

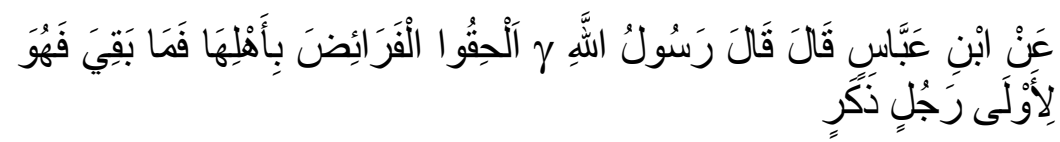

"Dari Ibnu Abbas, ia berkata, Rasulullah saw. bersabda: Berikanlah harta warisan kepada yang berhak mendapatkannya, sedangkan sisanya untuk laki-laki yang paling dekat keturunannya." (HR. Bukhari)

Hadis di atas menunjukan bahwa warisan hanya diberikan kepada orang yang berhak menerima warisan (ahli waris). Konsep waris dalam Islam erat kaitannya dengan distribusi kekayaan dalam keluarga, terutama keinginan agar tercipta keadilan dalam pembagian waris. Konsep waris Islam merupakan mekanisme distribusi kekayaan dan jaminan sosial dalam keluarga (Noor 2013). Pembagian harta waris dalam keluarga secara ekonomi dapat membantu dalam menciptakan distribusi kekayaan secara adil dan membantu mengurangi kesenjangan dalam distribusi kekayaan (M. U. Chapra, Islam dan Pembangunan Ekonomi 2000) . Dalam hal ini, membagikan harta waris kepada ahli waris yang berhak, baik disebabkan oleh hubungan perkawinan, kekerabatan maupun perwalian, secara langsung telah menciptakan jaminan sosial dalam keluarga agar di antara anggota keluarga tidak terjadi ketimpangan dalam memperoleh kekayaan.

\section{Jaminan Masyarakat}

Dari individu-individu, kemudian berkeluarga dan keluargakeluarga ini berhimpun dalam masyarakat. Oleh sebab itu, masingmasing individu dan keluarga tersebut terdapat hak dan kewajiban 
sehingga kehidupan di masyarakat akan damai dan sejahtera dalam lindungan Allah Swt. Selain ada kewajiban saling menjaga ketertiban dan keamanan, juga ada kewajiban saling menegakkan amar ma'rüf nahi munkar (perintah untuk mengajak hal-hal yang baik dan mencegah halhal yang buruk bagi masyarakat) (BAZNAS n.d.).

Jaminan masyarakat dapat diwujudkan melalui zakat. Untuk itu, zakat sangat erat kaitannya dengan dimensi sosial, moral, maupun ekonomi. Dalam dimensi sosial, zakat merupakan kewajiban sosial yang bersifat ibadah, karena zakat yang dikenakan terhadap harta individu ditujukan kepada masyarakat agar terpenuhi kebutuhan dan mengentaskan kemiskinan. Pada dimensi moral, zakat mengikis ketamakan dan keserakahan orang kaya. Sedangkan dalam dimensi ekonomi, zakat mencegah penumpukan harta kekayaan pada segelintir orang tertentu (Mannan 1993).

Kesadaran untuk menunaikan kewajiban zakat bagi setiap muslim merupakan kata kunci bagi terciptanya umat yang sejahtera. Kewajiban membayar zakat secara tegas telah tertulis dalam QS. al-Taubah [9]: 103:

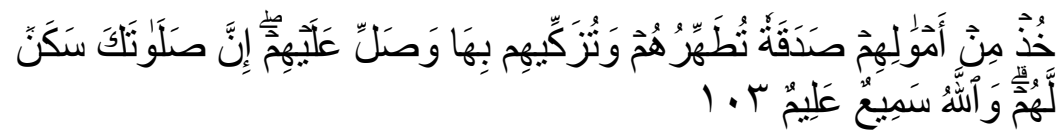

"Ambillah zakat dari sebagian harta mereka, dengan zakat itu kalian membersihkan dan mensucikan mereka dan berdoalah untuk mereka. Sesungguhnya doamu itu (menjadi) ketenteraman jiwa bagi mereka, dan Allah Maha Mendengar lagi Maha Mengetahui." (QS. alTaubah [9]: 103).

Ayat tersebut menjelaskan bahwa makna "bersih dan suci" dalam menunaikan zakat, memiliki makna penyucian bagi hati dan jiwa pada kecenderungan egoisme dan kecintaan terhadap harta duniawi, di samping penyucian terhadap harta benda itu sendiri. Sedangkan kata "ambillah" merupakan kata perintah untuk mengambil zakat (Quṭb 1994).

Economica: Jurnal Ekonomi Islam - Volume 8, Nomor 2 (2017) http://journal.walisongo.ac.id/index.php/economica 
Zakat merupakan rukun Islam dan salah satu bentuk kewajiban bagi seorang muslim untuk mengeluarkan sebagian pendapatan atau hartanya yang telah memenuhi syarat dan ketentuan (M. A. Khan 1989). Oleh karena itu, zakat sebagai jaminan sosial di dalam masyarakat yang bertujuan menciptakan pembangunan ekonomi yang lebih berkeadilan. Rasulullah saw. bersabda:

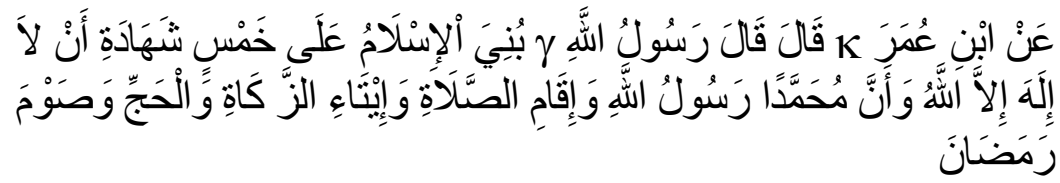

"Dari Ibnu Umar ra., ia berkata, Rasulullah saw. bersabda: Islam didirikan di atas lima pondasi: kesaksian bahwa tidak ada tuhan yang wajib disembah selain Allah dan kesaksian bahwa Muhammad adalah utusan Allah, mendirikan shalat, menunaikan zakat, melaksanakan haji, dan berpuasa bulan Ramadhan." (HR. Bukhari).

Zakat sejalan dengan prinsip utama tentang distribusi dalam ajaran Islam, yakni agar harta tidak hanya beredar di kalangan orang-orang kaya saja (Noor 2013). Prinsip tersebut menjadi aturan main yang harus dijalankan. Jika diabaikan, akan menimbulkan jurang yang dalam antara si miskin dan si kaya, serta tidak tercipta keadilan ekonomi di masyarakat.

Jaminan sosial lainnya di dalam masyarakat, juga dapat diwujudkan melalui infak dan sedekah. Dalam hal ini, infak diartikan mengeluarkan sebagian dari harta atau pendapatan untuk suatu kepentingan yang diperintahkan Islam. Jika zakat ada nișab-nya, maka infak tidak memiliki nișab. Selain tidak ada ketentuan nișab dalam infak, ketentuan tentang delapan golongan yang menerima zakat juga tidak berlaku di dalam infak. Jadi, infak boleh diberikan kepada siapa pun (Riyadi 2015). Sedangkan sedekah merupakan pemberian dari seorang muslim secara sukarela tanpa dibatasi oleh waktu dan jumlah tertentu, atau suatu pemberian yang dilakukan oleh seseorang sebagai kebaikan yang mengharap ridha Allah dan pahala semata. Berdasarkan pengertian tersebut, infak 
termasuk dalam kategori sedekah. Selain itu, sedekah dalam konsep Islam mempunyai arti yang lebih luas dan tidak hanya terbatas pada pemberian sesuatu yang bersifat material. Namun lebih dari itu, sedekah mencakup semua perbuatan baik, fisik maupun non-fisik. ${ }^{2}$

Penekanan terhadap sikap berinfak dan bersedekah merupakan sarana yang tepat untuk membantu menciptakan masyarakat yang peduli akan kondisi sosial, karena pada dasarnya setiap manusia harus menyadari bahwa setiap individu tidak dapat hidup sendiri dan selalu membutuhkan orang lain, sebagaimana firman Allah swt. dalam QS. alBaqarah [2]: 195:

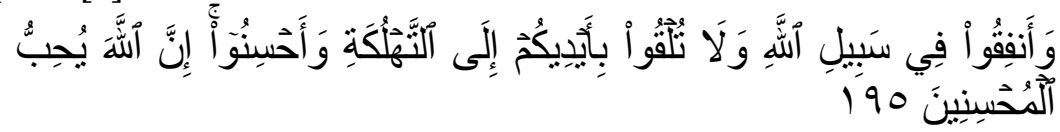

"Dan infakkanlah (harta bendamu) di jalan Allah, dan janganlah kalian menjatuhkan dirimu sendiri ke dalam kebinasaan, dan berbuat baiklah, karena sesungguhnya Allah menyukai orang-orang yang berbuat baik." (QS. al-Baqarah [2]: 195)

Dalam ayat di atas, Allah swt. memerintahkan manusia yang mempunyai harta supaya dibelanjakan untuk meringankan penderitaan fakir miskin, menolong orang-orang yang memerlukan pertolongan, dan untuk menolong hal-hal yang berguna kepada umat dan agama, sehingga akan membawa kebahagiaan dunia dan akhirat. Ayat tersebut juga menegaskan bahwa orang yang menjauhi ketamakan pada harta adalah orang yang beruntung (Hasan 2006). Oleh karena itu, harta yang dimiliki perlu diinfakkan di jalan Allah swt. supaya memperoleh pahala.

Jaminan sosial lainnya dalam masyarakat juga dapat melalui wakaf. Dalam hal ini, wakaf diartikan sebagai suatu jenis pemberian yang

\footnotetext{
2 Macam-macam sedekah antara lain bersedekah dengan harta, menolong orang, melakukan kebaikan, mendamaikan antara dua orang yang bermusuhan, menyingkirkan rintangan dari jalan, menunjukan sesuatu bagi orang yang tidak mengerti, dan lain-lainnya (Noor 2013).
}

Economica: Jurnal Ekonomi Islam - Volume 8, Nomor 2 (2017) http://journal.walisongo.ac.id/index.php/economica 
dilakukan dengan cara menahan (kepemilikan) untuk dimanfaatkan guna kepentingan umum (Noor 2013). Wakaf pada dasarnya sejalan dengan tujuan ekonomi, yakni menjadi cara yang lebih baik untuk mendistribusikan pendapatan di masyarakat dengan memberikan solusi terhadap pemenuhan kebutuhan publik (Cizakca 1998). Hal ini didasarkan pada firman Allah swt. dalam QS. al-Baqarah [2]: 261:

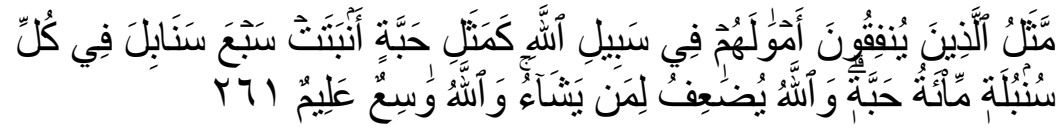

"Perumpamaan (nafkah yang dikeluarkan oleh) orang-orang yang menafkahkan hartanya di jalan Allah adalah serupa dengan sebutir benih yang menumbuhkan tujuh bulir, pada setiap bulir seratus biji. Allah melipatgandakan (ganjaran) bagi siapa yang dia kehendaki. Dan Allah Maha Luas (karunia-Nya) lagi Maha Mengetahui." (QS. alBaqarah [2]: 261)

Ayat di atas merupakan perumpamaan yang diberikan Allah swt. mengenai pahala yang dilipatgandakan bagi orang yang menafkahkan harta kekayaannya di jalan Allah dengan tujuan untuk mencari keridhaan-Nya (Kathīr 2000). Oleh karena itu, dapat dimaknai menafkahkan harta di jalan Allah meliputi belanja untuk kepentingan jihad, pembangunan perguruan, rumah sakit, usaha penyelidikan ilmiah, dan lain sebagainya.

Kesadaran untuk memahami dan mewakafkan sebagian hartanya memberikan kontribusi yang cukup besar dalam terciptanya keadilan distribusi di tengah-tengah masyarakat. Pada dasarnya, eksistensi harta wakaf berkaitan dengan kemanfaatan harta bagi kepentingan umat. Apabila eksistensi tersebut terealisir dengan baik, maka secara langsung dapat meningkatkan kesejahteraan sosial di masyarakat. Dengan demikian, jaminan sosial dalam masyarakat dapat melalui zakat, infak, sedekah, dan wakaf. Jika ditinjau dari kacamata makro, instrumen ini akan membentuk satu mekanisme jaminan sosial yang menyeluruh. 
Konstruksi Sistem Jaminan Sosial...

Bukan hanya untuk kebutuhan pokok masyarakat, namun dapat mengurangi pengangguran dan memperluas lapangan pekerjaan, bahkan dapat dikatakan sebagai pengentas kemiskinan.

\section{Jaminan Negara}

Negara bertanggung jawab penuh terhadap kesejahteraan setiap warga negaranya. Negara hadir dengan kewajiban menjamin terwujudnya suasana ta'abbud (kemudahan beribadah), kesejahteraan, keamanan, serta memberikan jaminan kebutuhan pokoknya. Oleh karena itu, jaminan sosial merupakan sebuah sistem yang sejatinya telah tercermin sejak berdirinya negara Islam. Sebagai contoh, adanya sebuah kebijakan yang diambil oleh Rasulullah Saw. yang menyediakan bantuan keuangan bagi orang miskin dan kekurangan dari lembaga keuangan rakyat. Siklus atas sistem ini adalah para pekerja yang mampu dalam bidang finansial memberi bantuan secara materi kepada mereka yang sakit, cacat, tidak mampu bekerja, sudah lanjut usia, dan lain sebagainya melalui negara sebagai penghubungnya (Syufa'at 2015).

Sistem jaminan sosial sejatinya merupakan pengejawantahkan interaksi sosial antara pihak satu dengan pihak yang lain, agar masingmasing dari anggota pihak saling diuntungkan. Hal ini didasarkan pada firman Allah swt. dalam QS. al-Qashash [28]: 77:

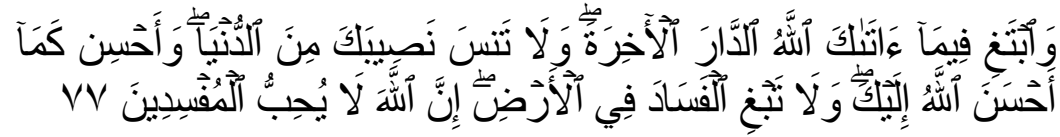

"Dan carilah pada apa yang telah dianugerahkan Allah kepadamu (kebahagiaan) negeri akhirat, dan janganlah kalian melupakan bagianmu dari (kenikmatan) duniawi dan berbuat baiklah (kepada orang lain) sebagaimana Allah telah berbuat baik kepadamu, dan janganlah kalian berbuat kerusakan di (muka) bumi. Sesungguhnya Allah tidak menyukai orang-orang yang berbuat kerusakan." (QS. alQashash [28]: 77) 
Ayat di atas memerintahkan untuk menafkahkan harta di jalan Allah dengan niat beramal untuk mencapai pahala di akhirat dan berbuat baik kepada hamba-hamba Allah sebagaimana Allah berbuat baik kepada manusia dengan mengaruniakan nikmat-Nya. Manusia dilarang membuat kerusakan di bumi dengan melampaui batas-batas Allah, karena Allah tidak meridhai orang-orang yang merusak dengan perbuatan buruk mereka itu (Shihab 1996).

Menurut Subianto, ayat tersebut dimaknai bahwa pembentukan dana jaminan sosial adalah bermula dari niat dan keinginan baik dari setiap individu dan masyarakat yang kemudian diantisipasi dan diformulasikan secara baik dan benar oleh pemerintah (negara) dalam bentuk kelembagaan dan sistem jaminan sosial (Subianto 2011). Dengan demikian, jaminan sosial ini diharapkan akan menunjang berbagai sektor pembangunan dan memperkuat kas negara. Manfaat signifikan atas kas negara yang kuat adalah jaminan sosial dari negara terhadap warganya dapat berjalan dengan baik.

Penjaminan minimal yang diberikan oleh negara adalah penjaminan dalam pemenuhan kebutuhan pokok bagi yang tidak dapat memenuhinya. Sedangkan dalam lingkup yang lebih luas, kebutuhan pokok bukan hanya dalam pengertian sandang, pangan, maupun papan. Namun, seperti jaminan keadilan, keamanan, serta perlindungan merupakan suatu hak warga negara yang harus dijamin oleh negaranya. Dalam hal ini, pemenuhan kebutuhan pokok didasarkan pada firman Allah swt. dalam QS. al-Isra [17]: 26:

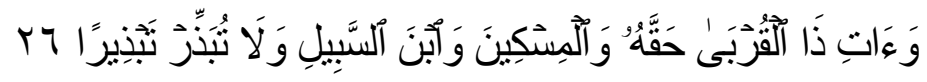

"Dan berikanlah kepada keluarga-keluarga yang dekat akan haknya, kepada orang miskin dan orang yang dalam perjalanan dan janganlah kamu menghambur-hamburkan (hartamu) secara boros." (QS. al-Isra [17]: 26) 
Sayyid Quṭb menafsirkan bahwa ayat tersebut memberikan makna tentang pemenuhan kebutuhan pokok yang meliputi kebutuhan sandang, pangan, dan papan yang layak agar manusia yang bermartabat (human dignity). Hal ini mengisyaratkan bahwa masalah kemiskinan merupakan beban bersama. Orang yang dalam keadaan miskin harus dibantu atas kemiskinan yang membelenggunya (Quṭb 1994).

Di Indonesia, upaya yang dilakukan oleh negara (pemerintah) dalam memberikan jaminan sosial terhadap warga negaranya adalah dengan membentuk Badan Penyelenggara Jaminan Sosial ( BPJS). Hal ini didasarkan pada Undang-Undang Nomor 40 Tahun 2004 tentang Sistem Jaminan Sosial Nasional (SJSN). Dalam undang-undang tersebut, secara tegas dinyatakan bahwa setiap orang berhak atas jaminan sosial untuk dapat memenuhi kebutuhan dasar hidup yang layak dan meningkatkan martabatnya menuju terwujudnya masyarakat Indonesia yang sejahtera,adil, dan makmur.

Pelaksanaan jaminan sosial di Indonesia secara umum dilakukan berdasarkan sistem jaminan sosial nasional bagi seluruh rakyat Indonesia, di mana jaminan sosial yang diterima oleh warga negara Indonesia meliputi jaminan kesehatan, jaminan kecelakaan kerja, jaminan hari tua, jaminan pensiun, dan jaminan kematian (2004, Sistem Jaminan Sosial Nasional, Bab VI: Program Jaminan Sosial, Pasal 18: Jenis Program Jaminan Sosial n.d.).

Konsep jaminan sosial yang dicanangkan pemerintah mencakup tiga pilar, yaitu: (1) Bantuan sosial yang berbentuk bantuan iuran oleh pemerintah, yang dimulai dengan bantuan iuran jaminan kesehatan kepada penduduk yang kurang mampu; (2) Asuransi sosial yang kepesertaan dan kontribusi iuran bersifat wajib (compulsory) bagi peserta dan pemberi kerja (dalam hal peserta adalah tenaga kerja di sektor formal). Pilar pertama dan pilar kedua merupakan kewajiban negara untuk menjamin agar setiap penduduk dapat memenuhi 
kebutuhan dasar hidup yang memungkinkannya berproduksi secara ekonomis dan sosial; (3) Asuransi sukarela (voluntary) sebagai tambahan (suplemen) setelah yang bersangkutan menjadi peserta asuransi sosial yang bersifat wajib. Pilar ketiga ini merupakan domain swasta dan perorangan untuk memenuhi kebutuhan kelompok dan atau perorangan di atas standar yang merupakan hak setiap orang yang dijamin negara (SJSN 2004).

Dengan demikian, jaminan sosial merupakan instrumental yang sangat penting dalam ekonomi Islam. Karena itu, melaksanakan jaminan sosial adalah upaya manusia dalam rangka mendekatkan diri kepada Allah Swt, sehingga menjadikan harta mereka bersih dan berkembang menghilangkan sifat ketamakan dan rakus, serta mementingkan diri sendiri. Namun demikian, jelas bahwa kebutuhan dasar masyarakat yang berupa kebutuhan pokok, keamanan, kesehatan, dan pendidikan, wajib disediakan oleh negara secara cuma-cuma bagi seluruh rakyatnya, baik kaya maupun miskin, tanpa ada diskriminasi sedikit pun.

\section{Simpulan}

Berdasarkan pembahasan di atas, dapat dipahami bahwa jaminan sosial merupakan bentuk perlindungan sosial untuk menjamin seluruh rakyat agar dapat memenuhi kebutuhan dasar hidupnya yang layak. Adapun asas jaminan sosial meliputi tiga hal, yaitu asas kemanusiaan, asas manfaat, dan asas keadilan. Ketiga asas ini merupakan landasan asas yang sustainable dan relatable, artinya antara asas yang satu dengan yang lain akan saling berdampingan dan tidak dapat berdiri sendiri untuk menopang dari sifat jaminan sosial.

Berkaitan dengan hal tersebut, konstruksi jaminan sosial dalam ekonomi Islam memiliki empat sistem tahapan, yaitu: (1) jaminan individu terhadap dirinya (jaminan individu), yang dapat berupa 
kewajiban bekerja untuk memenuhi kebutuhan hidupnya; (2) antara individu dengan keluarganya (jaminan keluarga), yang dapat berupa pembagian harta waeis; (3) individu dengan masyarakatnya (jaminan masyarakat), yang dapat berupa pendistribusia zakat, infak, sedekah, dan wakaf; dan (4) antara masyarakat dalam suatu negara (jaminan negara), yang dapat berupa pembentukan lembaga jaminan sosial masyarakat seperti halnya di Indonesia, membentuk Badan Penyelenggara Jaminan Sosial (BPJS). Oleh karena itu, konstruksi sistem jaminan sosial dalam ekonomi Islam ini menggambarkan bahwa jaminan itu berlapis-lapis. Apabila jaminan sosial mampu diselesaikan oleh individu, maka cukup di level individu. Namun apabila tak bisa diselesaikan di level individu, maka akan diselesaikan di level keluarga. Apabila tak selesai di level keluarga, maka akan diselesaikan di level masyarakat. Apabila jaminan sosial tak selesai di masyarakat, maka kewajiban negara menyelesaikannya.

\section{Daftar Pustaka}

(BAZNAS), Badan Amil Zakat Nasional. t.thn. "Jaminan Sosial di dalam Islam, Bayar Zakat, Bayar Infak, Bayar Wakaf." Diakses Oktober 30, 2016. http://pusat.baznas.go.id.

Aedy, Hasan. 2011. Teori dan Aplikasi Ekonomi Pembangunan Perspektif Islam. Yogyakarta: Graha Ilmu.

al-Arif, M. Nur Rianto. 2015. Pengantar Ekonomi Syariah: Teori dan Praktik. Bandung: Pustaka Setia.

al-Qardhawi, Yusuf. 2002. Teologi Kemiskinan: Doktrin Dasar dan Solusi Islam Atas Problem Kemiskinan. Yogyakarta: Mitra Pustaka.

al-Qashim, Abu Ubaid. 2006. Al-Amwal Ensiklopedia Keuangan Publik: Panduan Lengkap Mengelola Keuangan Zakat, Pajak, dan lain-lain. Jakarta: Gema Insani Press. 
Naerul Edwin Kiky Aprianto

Chapra, M. Umer. 1992. Islam and Economic Challenge. United Kingdom: International Institute of Islamic Thought (IIIT).

-. 2000. Islam dan Pembangunan Ekonomi. Dialihbahasakan oleh Ikhwan Abidin Basri. Jakarta: Gema Insani Press.

-. 1995. "The Islamic Welfare State and its Role in The Economy." Dalam Reading Public Finance in Islam, oleh Mahamoud A. Gulaid dan Mohamed Aden Abdullah (ed.), 77. Saudi Arabia: Islamic Research and Training Institute.

Chaudhry, Muhammad Syarif. 2012. Sistem Ekonomi Islam. Jakarta: Kencana.

Cizakca, Murat. 1998. "Awqaf in History and its Implications for Modern Islamic Economics." Jurnal Islamic Economic Studies 6 (1): 45.

Dahlan, Umi Afifah dan Ahmad. 2007. Konsep Negara Kesejahteraan. Purwokerto: STAIN Press.

Hasan, M. Ali. 2006. Zakat dan Infak. Jakarta: Kencana.

Isnaini Harahap, dkk. 2015. Hadis-Hadis Ekonomi. Jakarta: Prenadamedia Group.

Karim, Adiwarman Azwar. 2014. Sejarah Pemikiran Ekonomi Islam. Jakarta: RajaGrafindo Persada.

Kathīr, Ibnu. 2000. Tafsīr Ibnu Kathïr. Bandung: Sinar Baru Algesindo.

Khan, Muhammad Akram. 1989. Economics Teachings of Prophet Muhammad: A Select Anthology of Hadith Literature on Economics. Islamabad: International Institute of Islamics Economics.

-. 1994. An Introduction to Islamic Economics. Islamabad: International Institute of Islamic Thought.

Mannan, Muhammad Abdul. 1993. Ekonomi Islam: Teori dan Praktik. Yogyakarta: Dana Bakti Wakaf.

Mubarok, Jaih. 2008. Wakaf Produktif. Bandung: Simbiosa Rekatama Media.

Muzarie, Mukhlisin. 2010. Hukum Perwakafan dan Implikasinya terhadap Kesejahteraan Masyarakat. Jakarta: Kementerian Agama RI. 
Noor, Ruslan Abdul Ghofur. 2013. Konsep Distribusi dalam Ekonomi Islam dan Format Keadilan Ekonomi di Indonesia. Yogyakarta: Pustaka Pelajar.

Purwoko, Bambang. 2010. Jaminan Sosial dan Sistem Penyelenggaraannya: Gagasan dan Pandangan. Jakarta: Maganet Dutama Unggul.

Queisser, Monika. 1995. "Social Security in Developing Countries." Dalam Social Security in Social Market Economy, oleh Werner Lachmann and Jurgen Rosner (ed.), 273. Bornhein: Konrad Adenauerstiftung.

Quțb, Sayyid. 1994. al-'Adālah al-Ijtimā'iyyah fi al-Islām. Dialihbahasakan oleh Afif Muhammad. Bandung: Pustaka.

Rahman, Afzalur. 1995. Doktrin Ekonomi Islam. Dialihbahasakan oleh Soeroyo. Yogyakarta: Dana Bakti Wakaf.

Riyadi, Ika Yunia Fauzia dan Abdul Kadir. 2015. Prinsip Dasar Ekonomi Islam Perspektif Maqāshid Syarīah. Jakarta: Prenadamedia Group.

Shihab, M. Quraish. 1996. Wawasan al-Qur'an: Tafsir Maudhu'i atas Pelbagai Persoalan Umat. Bandung: Mizan.

SJSN, Tim. 2004. Desain Sistem Perlindungan Sosial Terpadu. Jakarta: Bapenas.

Subianto, Achmad. 2011. Sistem Jaminan Sosial Nasional. Jakarta: Gibon Books.

Syufa'at. 2015. Fikih Jaminan Sosial Perspektif Ibnu Hazm. Purwokerto: STAIN Press.

Undang-Undang Nomor 40 Tahun 2004. "Sistem Jaminan Sosial Nasional, Bab I Ketentuan Umum, Pasal 1, Ayat 1."

-. 2004, "Sistem Jaminan Sosial Nasional, Bab VI: Program Jaminan Sosial, Pasal 18: Jenis Program Jaminan Sosial." 